\title{
Diagnostics and treatment of insulinoma
}

\author{
Minireview
}

M. KOREN ${ }^{*}$, S. KINOVA

1st Department of Internal Medicine, University Hospital Bratislava, Medical Faculty of Comenius University, Bratislava, Slovakia

${ }^{\star}$ Correspondence: miso.koren@hotmail.sk

Received April 6, 2015 / Accepted May 18, 2015

\begin{abstract}
Insulinomas are the most common functioning pancreatic neuroendocrine neoplasms (pNENs), developed mainly from pancreatic islet cells. More than $90 \%$ of insulinomas are sporadic, benign and small sized. Autonomous production of insulin results in neuroglycopenic and adrenergic symptomatology with potential lethality. Surgery remains the only curative treatment with a high success rate. Preoperative tumor localization is challenging, but important for appropriate surgical approach. Metastatic forms represent a challenge, mainly on the field of therapy, with the need of tumor burden reduction and glycemia stabilization. The rarity of malignant forms limits reports on therapeutic strategies and outcome.

Authors present in this article a summarized overview of epidemiology, clinic, diagnostics and treatment of benign and malign forms of insulinomas.
\end{abstract}

Key words: insulinoma, neuroendocrine tumors, hypoglycemia

Insulinomas are the most common functioning endocrine neoplasms of the pancreas and represent $1-2 \%$ of all pancreatic neoplasms [1]. They are developed from pancreatic beta cells and the autonomous production of insulin is one of the most common causes of hypoglycemia by non-diabetic patients. Beside the production of insulin, production of even other hormones like gastrin, glucagon, somatostatin, serotonin, adrenocorticotropic and human choriogonadotropic hormone can be present [2]. Estimated incidence is $1-4$ people per million [3]. Insulinomas can occur at any age, but there is an age-specific incidence peak in the fifth decade of life in general population and in the second decade by patients with multiple endocrine neoplasms type 1 (MEN 1) [4 - 5]. Slightly higher incidence by women than by men is observed $(60: 40 \%)$. [2] Most of the insulinomas are located in the pancreas with equally distribution over its parts. Extrapancreatic occurrence of the primary lesion is extremely rare (incidence $<1 \%$ ) and the most frequent locations are duodenum, ileum, lungs, ovary and cervix $[1,6] .90 \%$ of insulinomas are benign, sporadic, solitary and smaller than $2 \mathrm{~cm}$. Less than $10 \%$ are malignant, with metastatic distribution into lymphatic nodes, liver, bones and peritoneum [7 - 9]. Approximately 5 - $10 \%$ of insulinomas are part of hereditary disorders like MEN 1, von Hippel-Lindau syndrome, tuberous sclerosis or neurofibromatosis type 1 and often prone to be multifocal $[4,10]$.

Given by the dominant benign nature of these neoplasms, the curability after surgery is more than $95 \%$. Recurrence is seen in $7 \%$ of the patients without MEN 1 at 20 years after surgery and in $21 \%$ at 20 years by patients with MEN 1. Median disease-free survival interval by malignant insulinomas after curative resection of 5 years has been demonstrated, but with recurrence of $63 \%$ at a median interval of 2,5-3 years. Palliative resection is associated with a median survival of 4 years, compared with 11 month after biopsy only [11, 12].

\section{Histopathology}

Majority of these neuroendocrine neoplasms appear well demarcated, but lack a well defined capsule and have a firm or rarely soft consistency, similar to other neuroendocrine neoplasms. Macroscopically, lesions appear reddish - brown in contrast to the surrounding yellowish pancreatic parenchyma 
Table 1. Grading of pancreatic neuroendocrine neoplasms including insulinoma [24, 25]

\begin{tabular}{|c|c|c|c|c|c|}
\hline Grade & ENETS 2010 & WHO 2010 & Differentiation & Ki- $67 \% *$ & $\begin{array}{l}\text { Mitotic count } \\
(10 \mathrm{HPF})^{* *}\end{array}$ \\
\hline Low & Neuroendocrine tumor grade 1 (G1) & Neuroendocrine neoplasm grade 1 & Well differentiated & $\leq 2$ & $<2$ \\
\hline Intermediate & Neuroendocrine tumor grade 2 (G2) & Neuroendocrine neoplasm grade 2 & Well differentiated & $3-20$ & $2-20$ \\
\hline \multirow[t]{2}{*}{ High } & Neuroendocrine carcinoma grade 3 (G3) small cell & Neuroendocrine carcinoma grade 3 & Poorly differentiated & $>20$ & $>20$ \\
\hline & Neuroendocrine carcinoma grade 3 (G3) large cell & & Poorly differentiated & $>20$ & $>20$ \\
\hline
\end{tabular}

${ }^{*}$ MIB1 antibody, \% of 2000 tumor cells in areas of highest nuclear labelling

$* * 10 \mathrm{HPF}$ : high power field $=2 \mathrm{~mm}^{2}$, at least 40 fields (40x magnification) evaluated in areas of highest mitotic density

[13]. Their size is generally $1-2 \mathrm{~cm}$, with a range of $0,1-9 \mathrm{~cm}$. Those that are larger than $3 \mathrm{~cm}$, are more likely to be malignant, with local invasion or metastases [14]. The majority of these neoplasms are well differentiated. They are composed of relatively uniform cuboidal cells with granular eosinophilic cytoplasm and centrally located round to oval nuclei that often display a distinct nucleolus. Mitoses are usually rare. Two principal histological patterns may be observed: a trabecular pattern including ribbon like, gyriform and glandular structures and solid medullary pattern or mixed pattern within the same neoplasm. The amount of vascular stroma and stromal sclerosis is variable. The hyaline stroma may show small foci of calcifications. At the tumor margin, normal pancreatic elements such as islets and ducts can be found entrapped in the tumor tissue [15 - 16]. By poorly differentiated neoplasms cytological pleiomorphism is pronounced, nuclei are hyperchromatic, mitosis are frequent and the histological pattern is variable [17]. Immunohistochemically beside the markers of neuroendocrine phenotype (expression of synaptophysin, chromogranin A, B, C, HISL-19, neuron specific enolase, protein convertases 2 and 3, lymphoreticular epitope Leu-7 and neural cell adhesion molecule NCAM or CD 56), expression of insulin and proin-

Table 2. Staging of pancreatic neuroendocrine neoplasms including insulinomas (ENETS) $[4,24]$

\begin{tabular}{ll}
\hline (T) Primary Tumor & \\
TX & Primary tumor cannot be assessed \\
T0 & No evidence of primary tumor \\
T1 & Tumor limited to the pancreas and size $<2 \mathrm{~cm}$ \\
T2 & Tumor limited to the pancreas and size $2-4 \mathrm{~cm}$ \\
T3 & Tumor limited to the pancreas and size $>4 \mathrm{~cm}$ or \\
& invading duodenum or bile duct \\
\hline (N) Regional Lymph & \\
Nodes & \\
NX & Regional lymph nodes cannot be assessed \\
N0 & No regional lymph node metastasis \\
N1 & Regional lymph node metastasis \\
\hline (M) Distant metastases & \\
MX & Distant metastases cannot be assessed \\
M0 & No distant metastasis \\
M1 & Distant metastasis \\
\hline
\end{tabular}

* For any $\mathrm{T}$, add $(\mathrm{m})$ for multiple tumors sulin can be identified. Immunohistochemical determination of insulin expression is not absolutely necessary for diagnosis. Some insulinomas do not stain positively for insulin despite the correct diagnosis, what might be caused by the rapid insulin release from the cells [18 - 21]. Insulinomas also commonly express islet amyloid polypeptide (IAPP) and in approximately $5 \%$ of these tumors IAPP may be precipitated as amyloid in the tumor stroma [22]. Assessment of somatostatin receptors expression can be useful by subsequent treatment with somatostatin analogues. Macroscopic evaluation (tumor size, number and location of lymph node metastases, extrapancreatic invasion, distant metastases), microscopic evaluation (mitotic index, angioinvasion, perineural invasion) and immunohistochemistry (chromogranin A, synaptophysin and insulin expression, Ki-67 index) is required for the histopathological diagnosis of insulinoma [23]. Most of insulinomas show benign behaviour, but they probably have malignant potential. Early appearance of symptoms of hypoglycemia and subsequent surgical treatment prevent from expressing this potential.

Despite new histopathological criteria, there are no conclusive histological or histochemical markers that reliably predict biological behaviour, and the definitive diagnosis of malignant insulinoma is still based on the presence of metastases or gross local invasion. Tumor size $\geq 2 \mathrm{~cm}, \mathrm{Ki}-67>2 \%$ and various molecular features (chromosomal instability, chromosomal loss of $3 p$ or $6 \mathrm{q}$, chromosomal gain on $7 \mathrm{q}, 12 \mathrm{q}$, or $14 \mathrm{q}$ ) are all predictors of metastatic disease and associated with decreased survival $[4,8,14]$.

For staging and grading WHO (World Health Organization and ENETS (European Neuroendocrine Tumor Society) guidelines are used. (Table $1-3$.)

Table 3. TNM classification of pancreatic neuroendocrine neoplasms including insulinomas $[4,24]$

\begin{tabular}{lccc}
\hline Stage & T & N & M \\
\hline I. & T1 & N0 & M0 \\
II.a & T2 & N0 & M0 \\
II.b & T3 & N0 & M0 \\
III.a & T4 & N0 & M0 \\
III.b & Any T & N1 & M0 \\
IV. & Any T & Any N & M1 \\
\hline
\end{tabular}




\section{Clinical manifestation}

The clinical symptoms are heterogeneous, not specific, episodic, sometimes bizarre and may differ among the patients. They result from usually episodic hypoglycemia due to endogenous hyperinsulinism. Episodic hypoglycemia precipitate in most cases after fasting (several hours after meal, fasting during night) or exercise, but postprandial hypoglycemia is also not rare $[26,27]$. In series of more than 200 patients with insulinomas, fasting hypoglycemia was reported in $73 \%$, postprandial in $6 \%$ and both fasting and postprandial state in $21 \%$ [28]. Hypoglycemia results in neuroglycopenic and autonomic symptoms with domination of signs of neuroglycopenia in more than $80 \%$ of patients. Common manifestation of neuroglycopenia is diplopia, blurred vision, recurrent headache, behavioural changes, confusion, agitation or slow reaction patterns, dizziness, weakness, amnesia. Prolonged hypoglycemia may lead to seizures, loss of consciousness, permanent brain damage or brain death. Autonomic symptoms comprise adrenergic and cholinergic symptoms such as palpitations, tremor, diaphoresis, hunger, paresthesia. However, by insulinoma patients, autonomic symptoms often lacking and by recurrent and prolonged hypoglycemia, impaired awareness of hypoglycemia is often present. Weight gain as a compensatory mechanism is found by $20-40 \%$ of these patients [ $29-32$ ]. In addition to insulin, tumorous cells can also secrete other hormones mentioned in the introduction. Due to a small size of these neoplasms, local signs from compression of the surrounding pancreatic tissue (f.e. abdominal pain, pancreatitis) are not frequent. Non-specific symptoms of metastatic forms are similar to other types of malignancies. Triad described by Whipple (1) neuroglycopenic symptoms (2) documented hypoglycemia (usually $\leq 2,5 \mathrm{mmol} / \mathrm{l}$ ) (3) relief of symptoms following glucose administration, is pathognomonic of insulinoma and it's the first step to diagnose this neoplasm $[33,34]$.

\section{Diagnostic modalities}

The diagnosis of insulinoma is based on patients symptoms, history, laboratory finding of endogenous hyperinsulinism, tumor localisation imaging and in sporadic cases genetic examination. Delays in the diagnosis are common because the

Table 4. Diagnostic criteria for insulinoma by $72-\mathrm{h}$ fast [40]

\begin{tabular}{ll}
\hline Plasma glucose & $\leq 2,2 \mathrm{mmol} / \mathrm{l}$ \\
Insulin & $\geq 6 \mathrm{mIU} / \mathrm{l}(\geq 36 \mathrm{pmol} / \mathrm{l})$ by ${ }^{\star} \mathrm{RIA}$, \\
& $\geq 3 \mathrm{mIU} / \mathrm{l} \mathrm{by}{ }^{* *} \mathrm{ICMA}$ \\
Proinsulin & $\geq 5 \mathrm{pmol} / \mathrm{l}$ \\
C-peptide & $\geq 200 \mathrm{pmol} / \mathrm{l}$ \\
B-hydroxybutyrate & $\leq 2,7 \mathrm{mmol} / \mathrm{l}$ \\
Sulphonylurea plasma/urine & negative
\end{tabular}

${ }^{\star}$ RIA - radioimmunoassay, ${ }^{* *}$ ICMA - immunochemiluminiscent assay symptoms usually precede detection of a tumor and there can be misattribution of the symptoms to psychiatric, neurological or cardiac disorders [35]. Start of diagnostic procedures depends on satisfying Whipple's triad.

\section{Laboratory}

Calculated insulin/glucose and insulin/C-peptide ratios are nowadays not used due to the fact that absolute insulin level is not elevated in all insulinoma patients. In addition, generally high level of proinsulin secreted by insulinoma cells is more suitable diagnostic marker [36]. Gold standard for biochemical proof of endogenous hyperinsulinemia is a supervised 72 - hour fasting test. The pathophysiological feature of this test is the fail to suppress insulin secretion during episodes of hypoglycemia [37]. Test starts in the morning with established intravenous access. During the fasting, patient is allowed to drink only water and can be encouraged to exercise. Samples of venous blood for plasma glucose level is taken every 6 hours, every $1-2$ hours by glycemia level $<3,3 \mathrm{mmol} / \mathrm{l}$ or by symptoms. When the patient develops symptoms and the glucose level is $\leq 2,2 \mathrm{mmol} / \mathrm{l}$, blood is also drawn for C-peptide, proinsulin, insulin and $B$ - hydroxybutyrate and we can end the test. Optional is intravenous administration of $1 \mathrm{mg}$ of glucagon with three glucose level measurements in $10 \mathrm{~min}$ interval at the end of test. From published reports, symptoms develop in $75 \%$ patients in $24 \mathrm{~h}, 92-96 \%$ in $48 \mathrm{~h}$ and $99 \%$ within $72 \mathrm{~h}[7,23,34]$. Some authors propose that $48 \mathrm{~h}$ fasting test should be enough for its high sensitivity $[38,39]$. The presence of hypoglycemia symptoms with fulfilment of the following six criteria is diagnostic for insulinoma [40] (Table 4.). A rise in plasma glucose concentration $\geq 1,4 \mathrm{mmol} / \mathrm{l}$ within $30 \mathrm{~min}$ in response to administered glucagon indicates hyperinsulinemia. $B$ - hydroxybutyrate levels are low by patients with insulinoma because of antiketogenic effect of insulin and can be very helpful criterion by patients with renal and liver insufficiency, where the clearance of insulin and C-peptide is impaired, with sensitivity and specificity close to $100 \%[41$, 42]. Accidental or intentional intake of antidiabetic drugs, notably insulin and sulphonylurea, can mimic clinical and laboratory signs of insulinoma. Fulfilment of these criteria will also exclude this common cause of hypoglycemia. It is also important to keep in mind that these criteria will not exclude nesidioblastosis, noninsulinoma pancreatogenous hypoglycemia syndrome (NIPHS) and multiple adenomas. Presence of glycated haemoglobin $<4 \%$ (IFCC) supports the diagnosis of insulinoma. Chromogranin A and neuron-specific enolase are used in diagnostic and follow up by pancreatic neuroendocrine neoplasms. Despite their reliability some studies showed that insulinoma cells do not secrete chromogranin A and neuron specific enolase into the circulation and therefore these markers are not suitable for diagnostic purposes by insulinomas $[43,44]$. Dynamic tests with tolbutamid, insulin or secretin are not commonly used. Serum calcium, gastrin and prolactin levels should be also examined as screening of MEN 1. Genetic 
examination for inherited diseases, in which insulinoma can be a part of, is indicated by insulinoma patients with multifocal lesions, recurrence after successful resection, positive family history of endocrinopathies, especially hyperparathyroidism and concomitant findings of hyperplasia, tumors or other findings typical for this disorders [4].

\section{Localization}

Imaging studies should be started after the diagnosis has been confirmed biochemically. The main disadvantage by localization of insulinomas is their average size $<2 \mathrm{~cm}$. Therefore, they are hard to visualise by conventional imaging methods. The main advantage is the intrapancreatic localisation in $99 \%$ of the cases. The preoperative imaging is not only useful to localize the tumor, but also to assess the extent of the disease, to choose the optimal surgical approach (laparotomy vs. laparoscopy, nucleation vs. resection) for successful initial resection and for additional treatment planning. Successful preoperative localization in $60 \%$ of the patients and success rate more than $90 \%$ by intraoperative exploration (palpation and ultrasound) is the argument of some surgeons not to insist on preoperative staging $[45,46]$. We do not dispose with imaging method with $100 \%$ sensitivity, so combination of several methods is usually necessary.

Sensitivity of transabdominal ultrasonography in insulinoma localization is poor, ranging from $9 \%$ to maximum $66-80 \%$. It can reveal only larger tumorous masses and metastasis. Limitations are mainly the tumor size, patient's habitus, physician's experience and the availability of dynamic ultrasonography $[47,48]$.

Computer tomography (CT) and/or magnetic resonance imaging (MRI) are the first line non-invasive imaging methods with CT sensitivity $30-94 \%$ and $40-95 \%$ for MRI. Higher rates by CT sensitivity are achieved by the use of multiphasic multidetector CT's. CT visualizes the location, relationship to other structures and the presence of metastasis. Insulinomas are typically isodense with the pancreas on pre-contrast images, hypervascular in early arterial phase with washout during late portal venous phase what is also typical for metastasis. More rarely are these neoplasms hyperdense to the pancreas, have nodular calcifications, or appear hypovascular, cystic or hypodense after contrast medium injection. Combined 3-phase CT and endoscopic ultrasound may increase sensitivity up to $100 \%[49,50]$. MRI is often complementary to CT, in order to confirm a suspected lesion on CT or to search for a tumor that CT was not able to visualise. MRI is preferred by patients with history of iodine allergy, renal insufficiency and to detect smaller liver metastasis. It is recommended to use T1 - weighted, T2 - weighted imaging and multiphasic (arterial, portal venous and delayed) dynamic MRI. Insulinomas are hypointense or isointense on T1 - weighted images and hyperintense on T2 - weighted images. On precontrast imaging, fat suppressed $\mathrm{T} 1$ and fat saturated T2 may improve the visualisation of the tumor. Dynamic contrast - enhanced imag- ing exhibit homogenous enhancement in primary tumor and metastasis, and can help to detect smaller lesions [51 - 54].

In cases of small insulinomas, not detected with mentioned imaging modalities, invasive procedures may be necessary for preoperative localization.

Endoscopic ultrasound (EUS), in experienced hands, is currently considered the best preoperative procedure to localize insulinoma with reported sensitivity of $87-94 \%$ by lesions in the head and body of the pancreas and $37-60 \%$ for tail lesions. EUS can visualize small (about $3 \mathrm{~mm}$ ) and multiple tumors and their relationship to vessels and pancreatic duct necessary for surgical approach. The appearance of insulinomas on EUS is quite characteristic, with most neoplasms homogeneously hypoechogenic, rounded in shape, and with distinct margins. Once the neoplasm is determined, fine needle aspiration (FNA) allows preoperative diagnosis of insulinoma. EUS guided FNA is becoming increasingly popular, and it seems to eventually become standard for the diagnosis and staging of pancreatic tumors. Nevertheless EUS is still second-line examination after conventional imaging due to invasivity, required sedation and operator dependent results [55 - 57].

Pancreatic angiography was considered as the "gold standard" for insulinoma localization in the past, but a tumor blush is seen in only $50-55 \%$ of patients. Invasivity, improvement of non-invasive imaging modalities and reported sensitivity of $30-64 \%$ have decreased its use $[58,59]$.

Transhepatic portal venous sampling (TPVS) was also considered as one of the most accurate tools for localization with sensitivity ranging between $77-100 \%$. This technique involves transcutaneous, trashepatic portal vein puncture, with sequential blood sampling for insulin levels from splenic, portal and superior mesenteric vein to determine the site of raised production. Considerable mortality, complications, invasivity, expensiveness and technical complexity are the limiting factors for its use [60].

Selective arterial calcium stimulation with hepatic venous sampling (ASVS) is the most precise preoperative localization method that combines and replaces previous two methods. Accuracy ranges from $88 \%$ to $100 \%$. This examination method combines visualization of the neoplasm with assessment of hormonal gradients after calcium stimulation. It is based on the fact that calcium is a potent secretagogue for abnormal $ß$-cells. An arterial catheter is placed in the truncus coeliacus for subsequent selective angiography. Also a venous catheter through femoral vein is placed into the right hepatic vein for blood sampling. An angiogram is performed followed by selective cannulation of the gastroduodenal, superior mesenteric, splenic and proper hepatic artery. Generally, the antero-superior site of the pancreatic head is supplied by gastroduodenal artery, infero-posterior site of the head and uncinate process by superior mesenteric artery, body and tail by splenic artery and liver tissue by hepatic artery. Calcium gluconate $(0,025 \mu \mathrm{g} / \mathrm{kg})$ is injected into each artery with subsequent sampling from the hepatic vein in $0,30,60$ and 
$120 \mathrm{sec}$ after injection for insulin measurement. Two-fold or greater increase in insulin level confirms the diagnosis and can localize the tumor in mentioned parts of pancreas or confirms liver metastases. Although ASVS has a high detection rate, it is not routinely used in most centres for its limitations identical to angiography and TPVS. ASVS is reserved for cases where insulinoma is strongly suspected but other modalities were not able to find the tumor and can help distinguish the rare forms of NIPHS [61 - 65].

Intraoperative localization techniques, which include palpation of the pancreas and intraoperative ultrasound (IOUS), are the most reliable way to localize small insulinomas. The sensitivity of both methods is reported as $75-95 \%$ and 80 - $100 \%$. Additional information about the relevant anatomy and relationship of the neoplasm to vessels and ducts helps to determine appropriate surgical approach. Moreover these techniques are mandatory by patients with suspected multiple lesions. Laparoscopic intraoperative ultrasound is an integral part of laparoscopic procedure and can lead to identifications of $>85 \%$ of insulinomas. Requirement for an experienced surgeon, to perform and interpret IOUS, or the necessary presence of radiologist are the main disadvantages and probably these modalities will remain confined to selected centres [66-68].

High expression of somatostatin receptors (SSTR) on NENs is the basis for the use of somatostatin receptor scintigraphy (SRS). ${ }^{111}$ In labelled somatostatin analogue octreotid ( ${ }^{111} \mathrm{In}$ pentetreotid) shares the binding profile of octreotid which makes it useful for imaging of somatostatin receptors 2 and 5 positive tumors. Octreoscan is routinely applied in localization of neuroendocrine neoplasms, in assessment of extend of the disease and necessary for planning the peptide receptor radionuclide therapy. Unfortunately insulinomas are lacking or express SSTR 2 and 5 only with low density, what decreases the sensitivity of this examination on about $50 \%$ by benign and about $70 \%$ by malign forms [69-71]. To reduce false negative findings, treatment with long-acting somatostatin analogues should be interrupted $3-6$ weeks before examination. Some agents such as interferon may upregulate SSTR and can lead to increased uptake without disease progression.

Promising are the first results achieved with the radiolabelled glucagon-like peptide - $1($ GLP -1$)$ analogue exendin - 4 (f.e. ${ }^{111}$ In-DOTA-exendin-4). Benign insulinomas were reported to express GLP-1 receptors with very high density. Some smaller studies report the sensitivity near $100 \%$ by localizing insulinomas. Additionally, malignant insulinomas frequently lack GLP-1 receptors (positive imaging only in $36 \%$ ) but, more often express SSTR. Combination of these two methods can not only help us to localize the tumorous masses but also probably give us information about malign or benign behaviour. Interestingly is also decreasing in plasma level glucose approximately 40 minutes after application of exendin- 4 by patients with insulinoma, not by normal subject. This unclear phenomenon can assessed as kind of provocative test in some insulinoma patients [72 - 75].
The results of ${ }^{18} \mathrm{~F}$ - fluorodeoxyglucose $\left({ }^{18} \mathrm{~F}\right.$ - FDG) positron emission tomography (PET) imaging of insulinomas are disappointing, presumably because of their low proliferative potential and unstable glucose levels [76]. Several investigators have published findings on patients with NEN imaged with PET using amino acid precursors. These studies are based on the fact that pancreatic endocrine tumors have the ability to take up and decarboxylase amine precursors. First results with the use of ${ }^{18} \mathrm{~F}$ - dihydroxyphenylalanine ( ${ }^{18} \mathrm{~F}$ - DOPA) PET imaging were encouraging in localization process. The following studies did not confirm these results and more data are necessary for recommendation of this method [67, $77-$ 79]. On the other hand, several studies supported the use of ${ }^{11} \mathrm{C}-5$ - hydroxy-tryptophan $\left({ }^{11} \mathrm{C}-5-\mathrm{HTP}\right)$ PET by detection of islet-cell tumors with superiority to SRS and ${ }^{18} \mathrm{~F}$-DOPA PET and sensitivity $>90 \%$. The reason for higher sensitivity by islet-cell tumors compared to other NENs is explained by highly active serotonin pathway by these neoplasms. Unfortunately its universal use is restricted by higher price and difficult synthesis [80, 81]. Receptor-based tracers such as somatostatin analogue can now be labelled with positron emitting isotopes. In the last years, octreotid or octreotate molecules combined with DOTA chelator and labelled with ${ }^{68} \mathrm{Ga}\left({ }^{68} \mathrm{Ga}\right.$ DOTA-NOC, ${ }^{68} \mathrm{Ga}$ DOTA-TOC and ${ }^{68} \mathrm{Ga}$ DOTA-TATE) are examined with promising results by staging of NENs. This PET imaging modalities proved to be more sensitive than SRS by different NENs (97 \% vs. 55 \%). Nevertheless, the low density of SSTR, especially type 2 and 5, on insulinomas is still the limiting factor $[82-84]$.

\section{Treatment}

Surgery and interventions. Surgery still remains the only curative treatment of insulinomas. Long term remission of $77-100 \%$ is nowadays achieved [85]. Type of the surgery depends on the type, size, location of the neoplasm and of its relationship to pancreatic duct, major vessels and adjacent organs. Improvement of the preoperative imaging techniques enabled surgeons to have an accurate preoperative topographic assessment and to choose an appropriate surgical approach [86]. Enucleation is the method of choice by sporadic, small $(<3 \mathrm{~cm})$, superficially localized insulinomas with distance of more than $2-3 \mathrm{~mm}$ between the tumor and the pancreatic duct $[7,87,88]$. Otherwise resection is indicated depending from the localization of the neoplasm (pancreaticoduodenectomy, partial pancreatectomy, distal pancreatectomy). For neoplasms in the pancreatic neck or adjacent body, central (middle) pancreatectomy is preferred by several groups, in order to preserve pancreatic parenchyma as much as possible, to reduce the risk of late exocrine / endocrine insufficiency [89-91].

During the operation, the entire pancreas has to be manually explored to exclude multiple lesions. Combination with intraoperative ultrasound in experienced hands, highers the chance to reveal occult or multifocal lesions up to $100 \%$ [92, 
93]. Complete resection should be confirmed intraoperatively by decreasing of serum insulin levels 20 minutes after resection compared to preoperative samples and the insulin/ glucose ratio should be $\leq 0,4$. Intraoperative frozen section is not routinely performed because it cannot usually assess malignant features accurately [94].

When insulinoma is not located either preoperatively or intraoperatively, blind distal resection is not recommended nowadays and the patient should be referred to an experienced centre for confirmation of the diagnosis and further localization studies [4].

Advances in laparoscopic techniques, instrumentation and more precise preoperative localization enabled surgeons to approach complex procedures laparoscopically (enucleation, distal pancreatectomy with/without splenectomy, pacreaticoduodenectomy or lymph node dissection). Laparoscopic ultrasound can be used to identify occult lesions missed by EUS, reveal multiple lesions or help to choose between enucleation or resection. The laparoscopic approach shortens the hospital stay, reduces time of return to full activity and reduces the risk of pancreatic fistulas. Conversion to an open procedure is reported as high as $33-40 \%$ [95 - 97.]

Over $75 \%$ of the patients with MEN 1 present with multiple insulinomas and other, often nonfunctioning islet cell tumors. For this reason and often recurrence after local tumor resection, subtotal pancreatic resection with IOUS guided enucleation of pancreatic head lesions is the procedure of choice for this specific group of patients [98 - 100].

Patients with malignant insulinoma represent double therapeutic challenge, i.e. that of the control of tumor progression and control of symptomatic hypoglycemia. 10-year survival of about $30 \%$ is reported by patients with metastatic disease, with heterogeneous courses, due to very variable progression rate [101]. Whenever it is possible, surgery must aim at totally removing the detectable lesions. Surgical removal of the tumor and its metastases, or even reduction of the tumor volume, may result in prolonged survival and reduces the hypoglycemic episodes. Improved outcome has been demonstrated in patients managed aggressively with debulking surgery with overall survival $71 \%$ (median 76 months), progression-free survival $5 \%$ (median 21 months) and symptom-free survival $24 \%$ (median 26 months) at 5 years [102]. Primary neoplasms should be managed by Whipple resection, distal pancreatectomy or larger resections with local lymph node resection. The absence of hepatic metastases is a major predictor of survival at 3 years [103]. Hepatic resection should be attempted in any patient if it is thought that at least $90 \%$ of the visible neoplasm could be removed. Unfortunately only $5-15 \%$ of the patients present with this kind of disease extend $[104,105]$.

If cytoreductive surgery (debulking) is not indicated, other non-surgical liver directed therapies for reduction of tumor burden and hypoglycemia control can be used. Selective arterial embolization, chemoembolization with doxorubicin or cisplatina-based regimens, radiofrequency ablation (RFA), cryoablation, alcohol ablation, laser induced thermotherapy
(LITT) and selective internal radiotherapy using ${ }^{90} \mathrm{Y}$ microspheres (SIRT) were used with acceptable results as part of combined therapy. Recording to some studies embolization methods have high symptomatic response rate of $40-90 \%$, but only $15-40 \%$ radiological response rate with median duration of $10-15$ months. Although all these interventions have been reported to improve symptomatic control in many patients with pNENs, information about the insulinoma subgroup or superiority of one of these techniques are generally lacking [106 - 108]

Liver transplantation remains an option by younger patients with unresectable disease, limited to the liver and symptomatology that cannot be controlled by other therapies. Reported 5 - year survival by patients with metastatic NEN after liver transplantation varies between $45-66 \%$ [109].

\section{Chemotherapy}

First-line chemotherapy for well - differentiated pNENs consists of streptozocin in combination with doxorubicin and/or 5-fluorouracil. Reported objective tumor response of these combinations ranges between $6 \%$ to $70 \%$ (average 25 $40 \%$ ) and symptomatic response of about $50 \%$ with duration of 20 - 24 months $[107,110,111]$ Recently quite favourable results have been reported using as a first-line chemotherapy capecitabin with tenozolomid, achieving $70 \%$ objective tumor response with median progression-free survival of 18 months. Capecitabin may also act as a radiosensiting agent prior to ${ }^{177} \mathrm{Lu}$ octreotate therapy [112]. Dacarbazine has been used as a second-line chemotherapy [113]. Cisplatin and etoposid are reserved for poor differentiated pNENs with the response rate of $40-70 \%$, however the duration of the responses is short [114]. Systemic chemotherapy can be additionally combined with arterial chemoperfusion by liver metastasis. Studies on the effect of chemotherapy on patients with pNENs differ in total number of patients in studies, in criteria of objective tumor response, include predominantly nonfunctioning tumors and informations about antisecretory effects of chemotherapy, especially on patients with metastatic insulinomas, are lacking.

Everolimus is an mTOR (mammalian target of rapamycin) inhibitor used in treatment of neuroendocrine neoplasms, based on the results of RADIANT-3 study. This study proved prolonged progression free survival (PFS) from 4,6 to 11,0 months by patients with progressive, low or intermediate pNENs, treated with $10 \mathrm{mg}$ daily dose of everolimus, with low toxicity [115]. Exact numbers of included malign insulinoma patients were not published. Recently, other small studies or case reports with insulinoma patients not only support the anti-tumor effect of everolimus, but also confirm its good effect by glycemia control. Its hyperglycemic effect is probably dose dependent, mediated through suppression of insulin production, induction of peripheral insulin resistance and reduction of hormonal active mass [116 - 118]. Sunitinib, a multiple tyrosine kinase inhibitor, showed in SUN 111 study, similar 
results of prolonged PFS (5,5 vs. 11,4 months) as everolimus by patients with advanced well differentiated pNENs. Again, only four patients with metastatic insulinoma were included [119]. Finally, everolimus and sunitinib are still remaining a treatment option after failure of chemotherapy in pNENs, but can be considered as first-line therapy in selected cases as an alternative treatment, if locoregional therapies or chemotherapy are not feasible [4].

\section{Peptide receptor radionuclide therapy (PRRT)}

Radiolabelled somatostatin analogue therapy is a novel treatment for inoperable or metastatic neuroendocrine tumors, including pNENs. It involves the high specificity binding of radiolabelled peptide hormone analogue to somatostatin receptor subtypes on tumor cells, the rapid clearance of residual activity and the long retention of the radioactivity in the tumor cells. As a precondition for therapeutic effect of this method, presence of SSTR subtypes on tumor cells has to be demonstrated. For this purpose, ${ }^{111} \mathrm{In}$-DTPA-octreotid scintigraphy or ${ }^{68} \mathrm{Ga}$-DOTANOC PET, and SSTR immunochemistry on tumor specimens is used. Somatostatin analogues coupled with ${ }^{90} \mathrm{Y},{ }^{177} \mathrm{Lu}$ and ${ }^{111}$ In are used for treatment $[107,120]$. Higher affinity to SSTR 2 favours the use of octreotate molecules compared to octreotid and higher tumor radioactivity uptake the use of ${ }^{177} \mathrm{Lu}$ and ${ }^{90} \mathrm{Y}$ compared to ${ }^{111} \mathrm{In}$ as a radionuclide [121]. To maximize the effect of therapy, treatment with short-acting somatostatin analogues has to be discontinued 1 day before PRRT and 6 weeks by the treatment with long-acting somatostatin analogues. A study with 129 patients with malignant pNEN treated with $\left[{ }^{177} \mathrm{Lu}-\mathrm{DOTA}{ }^{0}, \mathrm{Tyr}^{3}\right]$ octreotate observed complete remission in $2 \%$, partial response in $32 \%$ and stabilization in $34 \%$ of the patients, due to RECIST criteria. This study also included 5 patients with metastatic insulinomas. Three achieved partial response, one stabilization and one progressed. Stabilization of glycemia levels by persistent hypoglycemia was also observed in this group with duration of $20-65$ months, even if tumor progression occurred after initial favourable tumor responses. Adverse events by this therapy consist dominantly of gastrointestinal symptoms, myelosuppression, renal and liver impairment and transient male primary hypogonadism $[118,122]$. At present, no controlled studies have demonstrated prolonged survival, but PRRT is undergoing further evaluation, because of its promising results.

\section{Medical treatment}

Medical treatment is only reserved for preoperative glycemia stabilization. Long term treatment is indicated if surgery is technically impossible, contraindicated or refused by the patient.

Dietary regimen can include frequent small portion of meal with low glycemic index, if necessary night enteral feeding via nasogastric/nasojejunal tube and in advanced stages continuous intravenous glucose application.

Diazoxide, an antihypertensive agent, is the most effective drug to counter hypoglycemia by insulinomas. Hyperglycemia effect is mediated through adrenergic suppression of insulin release from $\beta$ cells, increase of hepatic gluconeogenesis and reduced glucose uptake by muscle cells. Control of symptomatic hypoglycemia can be achieved in about $50 \%$ of the patients, and the most common daily dose varies between 200 to $600 \mathrm{mg}$. Unfortunately, half of the patients demonstrate adverse effects like fluid retention with oedema and weight gain, nausea, hirsutism and cutaneous rashes. Although, f.e. thiazide diuretics can be added to prevent fluid retention, adverse effects are frequent reason for treatment discontinuation $[123,124]$.

Somatostatin analogues (octreotide, lanreotide) can be useful in preventing hypoglycemia in SSTR 2 positive tumors, what is approximately in $50-60 \%$ of the patients. Therapy may be less effective, or require higher doses in malignant insulinomas. In some patients, treatment can worsen hypoglycemia, probably due to greater suppression of glucagon and growth hormone than insulin. Treatment should be started with short-acting octreotid (daily dose of $50-2000 \mu \mathrm{g}$ ) with dose titration according to clinical response, and afterwards transferred to slow-release octreotid ( 10 - 30 mg every 28 days) or lanreotid (60 - 120mg every 28 days). Predicting therapeutic success remains difficult. Short $100 \mu \mathrm{g}$ octreotid test and demonstration of SSTR 2 on specimens can be useful. ${ }^{111} \mathrm{In}$ pentetreotid scintigraphy showed inconsistent at predicting response $[125,126]$. Recent studies demonstrated prolonged progression free survival by patients with metastatic midgut NENs (PROMID study) and enteropancreatic NENs (CLARINET study) treated with somatostatin analogues. No study has shown prolonged survival. Nevertheless, symptomatic control, suggested antiproliferative effect and a good tolerability of the treatment make this therapy reasonable for all patients [127, 128]. Additionally, antiproliferative and antisecretory effect of a new somatostatin analogue (pasireotid) with extended binding on SSTR 1, 2, 3 and 5 is ongoing [129].

Glucocorticoids should be reserved for resistant hypoglycemia, because of their well-known adverse effects. They decrease insulin secretion, increase insulin resistance and hepatic glucose production. Prednisone is the most common used steroid with the recommended daily dose between 2,5 $\mathrm{mg}$ to $60 \mathrm{mg}$ [130].

Interferon $\alpha$ is a biological agent with anti-tumor effect with direct action on cell cycling, angiogenesis and modulation of immune response. Its antiproliferative effect by metastatic pNENs is comparable to somatostatin analogues; also biochemical response in $50-60 \%$ of patients was demonstrated. Combination with somatostatin analogues showed to be safe, but with uncertain additive benefits. On the other hand, combination with streptozocin-based chemotherapy showed significant adverse effects without additional benefit. Considering its known adverse effects and uncertain benefit 
in combination with other therapies, interferon is not to be generally recommended by treatment of insulinomas, but only in selected cases [65, 131, 132].

Other medications like verapamil, phenytoin and propranolol were employed in glycaemia control with diverse results [4].

\section{Conclusion}

Insulinomas is a rare pancreatic neuroendocrine neoplasm and the most common cause of endogenous hyperinsulinism. Because of the average small size of these tumors, localization of the primary tumor can be a real challenge. Multimodal approach with use of non-invasive and invasive imaging methods is to be recommended. Intraoperative localization plays an important role by multifocal and occult lesions. Surgery is the only curative treatment and should be always considered in the management of benign or malign insulinomas. The extreme rarity of malignant insulinomas and the resulting lack of experience and standardized therapy guidelines are the major limiting factors in their management. Aggressive approach to control the tumorous masses as well as glycemic control is recommended. Newer therapeutic modalities (everolimus, sunitinib, capecitabine, temozolomide, SIRT, PRRT) have promising results, but their stable role in the management of insulinomas have yet to be examined by following studies.

\section{References}

[1] OKABAYASHI T, SHIMA Y, SUMIYOSHI T, KOZUKI A, ITO $S$ et al. Diagnosis and management of insulinoma. World J Gastroenterol 2013; 19: 829-837 http://dx.doi.org/10.3748/ wjg.v19.i6.829

[2] GOSWAMI J, SOMKUWAR P, NALK Y. Insulinoma and anaesthetic implications. Indian J Anaesth 2012; 56: 117-122 http://dx.doi.org/10.4103/0019-5049.96301

[3] KULKE MH, ANTHONY LB, BUSHNELL DL, DE HERDER WW, GOLDSMITH SJ et al. NANETS Treatment guidelines: Well differentiated Neuroendocrine Tumors of the Stomach and Pancreas. Pancreas 2010; 39: 735-752 http://dx.doi. org/10.1097/MPA.0b013e3181ebb168

[4] JENSEN RT, CADIOT G, BRANDI ML, DE HERDER WW, KALTAS $G$ et al. ENETS Consensus Guidelines for the Management of Patients with Digestive Neuroendocrine Neoplasms: Functional Pancreatic Endocrine Tumor Syndromes. Neuroendocrinology 2012; 95: 98-119 http://dx.doi. org/10.1159/000335591

[5] OBERG K. Pancreatic endocrine tumors. Semin Oncol 2010; 37: 594-618 http://dx.doi.org/10.1053/j. seminoncol.2010.10.014

[6] PATEL S, NARWARIA M, PAREKH D, SHAH V. Insulinoma: Case report and Review of Diagnostic and Treatment Modalities. J Assoc Psysicians India 2013; 61: 423-426

[7] TUCKER ON, CROTTY PL, CONLON KC. The management of insulinoma. Br J Surg 2006; 93: 264-275 http://dx.doi. org/10.1002/bjs. 5280
[8] DE HERDER WW, VAN SHAIK E, KWEKKEBOOM D, FEELDERS RA. New therapeutic options for metastatic malignant insulinomas. Clin Endocrinol 2011; 75: 277-284 http://dx.doi.org/10.1111/j.1365-2265.2011.04145.x

[9] FERRER-GARCIA JC, GONZALEZ-CRUZ VI, NAVASDESOLIS S, CIVERA-ANDRES M, MORILLAS-ARINO C. Management of malignant insulinoma. Clin Transl Oncol 2013; 15: 725-731 http://dx.doi.org/10.1007/s12094-0120996-7

[10] IGAZ P, IGAZ I, RACZ K, TULASSAY Z. Hereditary tumours of the endocrine pancreas. Orv Hetil 2006; 147: 195-200

[11] SOGA J, YAKUWA Y, OSAKA M. Insulinoma/hypoglycemic syndrome: a statistical evaluation of 1085 reported cases of Japanese series. J Exp Clin Cancer Res 1998; 17: 379-388

[12] DANFORTH DN, GORDEN P, BRENNAN MF. Metastatic insulin-secreting carcinoma of the pancreas: clinical course and the role of surgery. Surgery 1984; 96: 1027-1037

[13] DAVTYAN H, NIEBERG R, REBER HA. Pancreatic cystic endocrine neoplasms. Pancreas 1990; 5: 230-233 http://dx.doi. org/10.1097/00006676-199003000-00017

[14] MITTENDORF EA, LIU YC, MCHENRY CHR. Giant insulinoma: Case Report and Review of the Literature. J Clin Endocrinol Metab 2005; 90: 575-580 http://dx.doi. org/10.1210/jc.2004-0825

[15] PEREZ-MONTIEL MD, FRANKEL WL, SUSTER S. Neuroendocrine carcinomas in the pancreas with rhabdoid features. Am J Surg Pathol 2003; 27: 642-649 http://dx.doi. org/10.1097/00000478-200305000-00007

[16] VAN EEDEN S, DE LENG WWJ, OFFERHAUS GJ, MORSINK FH, WETERMAN MA et al. Ductuloinsular tumors of the pancreas. Endocrine tumors with entrapped nonneoplastic ductules. Am J Surg Pathol 2004; 28: 813-820 http://dx.doi. org/10.1097/01.pas.0000112546.57641.c7

[17] ZEE SY, HOCHWALD SN, CONLON KC, BRENNAN MF, KLIMSTRA DS. Pleomorphic pancreatic endocrine neoplasms: a variant commonly confused with adenocarcinoma. Am J Surg Pathol 2005; 29: 1194-1200 http://dx.doi. org/10.1097/01.pas.0000164370.81132.25

[18] LLOYD RV. Practical markers used in the diagnosis of neuroendocrine tumors. Endocr Pathol 2003; 14: 293-301 http:// dx.doi.org/10.1385/EP:14:4:293

[19] LLOYD RV, MERVAK T, SCHMIDT K, WARNER TF, WILSON BS. Immunohistochemical detection of chromogranin and neuron-specific enolase in pancreatic endocrine neoplasms. Am J Surg Pathol 1984; 8: 607-614 http://dx.doi. org/10.1097/00000478-198408000-00004

[20] KRISCH K, HORVAT G, KRISH I, WENGLER G, ALIBEIK $\mathrm{H}$ et al. Immunohistochemical characterization of a novel secretory protein (defined by monoclonal antibody HISL-19) of a peptide hormone producing cells which is distinct from chromogranin A, B and C. Lab Invest 1988; 58: 411-420

[21] ROTH J, KLOPPEL G, MADSEN OD, STORCH MJ, HEITZ PU. Distribution patterns of proinsulin and insulin in human insulinomas: an immunohistochemical analyses in 76 tumors. Virchows Arch B Cell Pathol Incl Mol Pathol 1992; 63: 51-61 http://dx.doi.org/10.1007/BF02899244 
[22] RINDI G, TERENGHI G, WESTERMARK G, WESTERMARK P, MOSCOCO G et al. Islet amyloid polypeptide in proliferating pancreatic B cells during development, hyperplasia and neoplasia in humans and mice. Am J Surg Pathol 1991; 138: 1321-1334

[23] DE HERDER WW, NIEDERLE B, SCOAZEC JY, PAUWELS S, KLOPPEL G. Well-differentiated Pancreatic Tumor/Carcinoma: Insulinoma. Neuroendocrinology 2006; 84: 183-188 http://dx.doi.org/10.1159/000098010

[24] RINDI G, KLOPPEL H, ALHMAN H, CAPLIN M, COUVELARD A et al. TNM staging of foregut (neuro)endocrine tumors: a consensus proposal including a grading system. Virchows Arch 2006; 449: 395-401 http://dx.doi.org/10.1007/ s00428-006-0250-1

[25] BOSMAN F, CARNEIRO F, HRUBAN R, THEISE N, EDITORS. WHO Classification of Tumours of the Digestive System. Lyon: IARC press, 2010

[26] LAIRMORE TC, MOLEY JF. Endocrine pancreatic tumors. Scand J Surg 2004; 93: 311-315

[27] OBERG K, ERIKSSON B. Endocrine tumours of the pancreas. Best Pract Res Clin Gastroenterol 2005; 19: 753-781 http:// dx.doi.org/10.1016/j.bpg.2005.06.002

[28] PLACZKOWSKI KA, VELLA A, THOMPSON GB, GRANT CS, READING CC et al. Secular trends in the presentation and management of functioning insulinoma at the Mayo Clinic 1987-2007. J Clin Endocrinol Metab 2009;94:1987-2007 http://dx.doi.org/10.1210/jc.2008-2031

[29] MOKAN M, GALAJDA P. Problematika diferenciálnej diagnostiky paraneoplastickej hypoglykémie. Vnitř Lék 2014;60:730-735

[30] CRYER PE. Symptoms of hypoglycemia, thresholds for their occurrence, and hypoglycemia unawareness. Endocrinol Metab Clin North Am 1999; 28: 495-500 http://dx.doi. org/10.1016/S0889-8529(05)70084-0

[31] GRAVES TD, GANDHI S, SMITH SJ, SISODYA SM, CONWAY GS. Misdiagnosis of seizures: insulinoma presenting as adult-onset seizure disorder. J Neurol Neurosurg Psychiatry 2004; 75: 1091-1092 http://dx.doi.org/10.1136/ jnnp.2003.029249

[32] DE ROSA MA, CRYER PW. Hypoglycemia and the sympathoadrenal system: neurogenic symptoms are largely the result of sympathetic neural, rather than adrenomedullary activation. Am J Physiol Metab 2004; 287: E32-E41

[33] WHIPPLE AO, FRANTZ VK. Adenoma of islets cells with hyperinsulinism. Ann Surg 1935; 101: 1299-1365 http:// dx.doi.org/10.1097/00000658-193506000-00001

[34] VALDAKIS D, KAROUBALIS J, PAPPA T, PIADITIS G, ZOGRAFOS GN. Pancreatic insulinomas: Current issues and trends. Hepatobiliary Pancreat Dis Int 2010; 9: 234-241

[35] SUZUKI K, MIYAMOTO M, MIYAMOTO T, HIRATA K. Insulinoma with early-morning abnormal behavior. Intern Med 2007; 46: 405-408 http://dx.doi.org/10.2169/ internalmedicine.46.6071

[36] VEZZOSI D, BENNET A, FAUVEL J, CARON P. Insulin, C-peptide and proinsulin for the biochemical diagnosis of hypoglycaemia related to endogenous hyperinsulinism. Eur
J Endocrinol 2007; 157: 75-83 http://dx.doi.org/10.1530/EJE07-0109

[37] SERVICE FJ, NATT N. The prolonged fast. J Clin Endocrinol Metab 2000; 85: 3973-3974 http://dx.doi.org/10.1210/ jcem.85.11.6934

[38] HIRSHBERG B, LIVI A, BARTLETT DL, LIBUTTI SK, ALEXANDER HR et al. Forty-eight-hour fast: diagnostic test for insulinoma. J Clin Endocrinol 2000; 85: 3222-3226 http:// dx.doi.org/10.1210/jcem.85.9.6807

[39] QUINKLER M, STRELOW F, PIRLICH M, ROHDE W, LOCHS $\mathrm{H}$ et al. Assessment of suspected insulinoma by 48-hour fasting test: a retrospective monocentric study of 23 cases. Horm Metab Res 2007; 39: 507-510 http://dx.doi. org/10.1055/s-2007-982516

[40] VINIK AI, WOLTERING EA, WARNER RRP, CAPLIN M, O'DORISIO TM et al. NANETS Consensus Guidelines for the Diagnosis of Neuroendocrine Tumor. Pancreas 2010; 39: 713-734 http://dx.doi.org/10.1097/MPA.0b013e3181ebaffd

[41] CRYER PE, AXELROD L, GROSSMAN AB, HELLER SR, MONTORI VM. Evaluation and management of adult hypoglycemic disorders: an Endocrine Society Clinical Practice Guideline. J Clin Endocrinol Metab 2009; 94: 709-728 http:// dx.doi.org/10.1210/jc.2008-1410

[42] O'Brien T, O'BRIEN PC, SERVICE FJ. Insulin surrogates insulnoma. J Clin Endocrinol Metab 1993; 77: 448-451

[43] QIAO XW, QIU L, CHEN YJ, MENG CT, SUN Z. Chromogranin $\mathrm{A}$ is a reliable serum diagnostic biomarker for pancreatic neuroendocrine tumors but not for insulinomas. BMC Endocr Disord. 2014; 14: 64 http://dx.doi. org/10.1186/1472-6823-14-64

[44] WIESLI P, UTHOFF H, PERREN A, PFAMMATTER T, ZWIMPFER $C$ et al. Are biochemical markers of neuroendocrine tumors coreleased with insulin following local calcium stimulation in patients with insulinomas? Pancreas 2011; 40: 995-999 http://dx.doi.org/10.1097/ MPA.0b013e31821ffce1

[45] BUOKHAM MP, KARAM JM, SHAVER J, SIPERSTEIN AE, DELORIMIER AA et al. Localisation of insulinomas. Arch Surg 1999; 134: 818-822 http://dx.doi.org/10.1001/ archsurg.134.8.818

[46] HASHIMOTO LA, WALSH RM. Preoperative localisation of insulinomas is not necessary. J Am Coll Surg. 1999; 189: 368-373 http://dx.doi.org/10.1016/S1072-7515(99)00163-5

[47] OSHIKAWA O, TANAKA S, IOKA T, NAKAIZUMI A, HAMADA Y et al. Dynamic sonography of pancreatic tumors: comparison with dynamic CT. Am J Roentgenol 2002; 178: 1133-1137 http://dx.doi.org/10.2214/ajr.178.5.1781133

[48] ROCKALL AG, REZNEK RH. Imaging of neuroendocrine tumours (CT/MR/US). Best Pract Res Clin Endocrinol Metab 2007; 21: 43-68 http://dx.doi.org/10.1016/j.beem.2007.01.003

[49] NOONE TC, HOSEY J, FIRAT Z, SEMELKA RC. Imaging and localization of islet-cell tumours of the pancreas on CT and MRI. Best Pract Res Clin Endocrinol Metab 2005; 19: 195-211 http://dx.doi.org/10.1016/j.beem.2004.11.013

[50] GOUYA H, VIGNAUX O, AUGUI J, DOUSSET B, PALAZZO L et al. CT, endoscopic sonography, and combined protocol for preoperative evaluation of pancreatic insulinomas. Am J 
Roentgenol 2003; 181: 987-992 http://dx.doi.org/10.2214/ ajr.181.4.1810987

[51] Mcauley G, Delaney H, COlville J, LYBURN I, WORSLEY D et al. Multimodality preoperative imaging of pancreatic insulinomas. Clin Radiol 2005; 60: 1039-1050 http://dx.doi.org/10.1016/j.crad.2005.06.005

[52] ANAYE A, MATHIEU A, CLOSSET J, BALI MA, METENS $\mathrm{T}$ et al. Successful preoperative localization of small pancreatic insulinoma by diffusion-weighted MRI. JOP 2009; 10 : 528-53

[53] SEMELKA RC, CUSTODIO CM, CEM BN, WOOSLEY JT. Neuroendocrine tumors of the pancreas: spectrum of appearances on MRI. J Magn Reson Imaging 2000; 11: 141-148 http:// dx.doi.org/10.1002/(SICI)1522-2586(200002)11:2<141::AIDIMRI10>3.0.CO;2-U

[54] DEBRAY MP, GEOFFROY O, LAISSY JP, LEBTAHI R, SILBERMANN-HOFFMANN O et al. Imaging appearances of metastases from neuroendocrine tumours of the pancreas. Br J Radiol 2001; 74: 1065-1070 http://dx.doi.org/10.1259/ bjr.74.887.741065

[55] KANN PH, ROTHMUND M, ZIELKE A. Endoscopic ultrasound imaging of insulinomas: limitations and clinical relevance. Exp Clin Endocrinol Diabetes 2005; 113: 471-474 http://dx.doi.org/10.1055/s-2005-865752

[56] McLEAN AM, FAIRCLOUGH PD. Endoscopic ultrasound in localisation of pancreatic islet cell tumours. Best Pract Res Ciln Endocrinol Metab 2005; 19: 177-193 http://dx.doi. org/10.1016/j.beem.2004.11.012

[57] PATEL KK, KIM MK. Neuroendocrine tumors of the pancreas: endoscopic diagnosis. Curr Opin Gastroenterol 2008; 24 : 638-642 http://dx.doi.org/10.1097/MOG.0b013e32830bf7fb

[58] ABBOUD B, BOUJAOUDE J. Occult sporadic insulinoma: Localization and surgical strategy. World J Gastroenterol 2008; 14: 657-665 http://dx.doi.org/10.3748/wjg.14.657

[59] ROCHE A, RAISONNIER A, GILLON-SAVOURET MC. Pancreatic venous sampling and arteriography in localizing insulinomas and gastrinomas: procedure and results in 55 cases. Radiology 1982; 145: 621-627 http://dx.doi.org/10.1148/ radiology.145.3.6292994

[60] ERICKSON D, KUDYA YC, EBERSOLD MJ, THOMPSON GB, GRANT CS et al. Benign paraganggliomas: clinical presentation and treatment outcomes in 236 patients. J Clin Endocrinol Metab 2001; 86: 5210-5216 http://dx.doi. org/10.1210/jcem.86.11.8034

[61] DOPPMAN JL, CHANG R, FRAKER DL, NORTON JA, ALEXANDER HR et al. Localization of insulinomas to regions of the pancreas by intra-arterial stimulation with calcium. Ann Intern Med 1995; 123: 269-273 http://dx.doi. org/10.7326/0003-4819-123-4-199508150-00004

[62] TSENG LM, CHEN JY, WON JG, TSENG HS, YANG HA et al. The role of intraarterial calcium stimulation test with hepatic venous sampling (IACS) in the management of occult insulinomas. Ann Surg Oncol 2007; 14: 2121-2127 http:// dx.doi.org/10.1245/s10434-007-9398-4

[63] MORITA S, MACHIDA H, KUWATSURU R, SAITO N, SUZUKI K et al. Preoperative localization of pancreatic insulinoma by super selective arterial stimulation with venous sampling. Abdom Imaging 2007; 32: 126-128 http://dx.doi. org/10.1007/s00261-006-9040-0

[64] GUTTIER JM, KAM A, CHANG R, SKARULIS MC, COCHRAN C et al. Localization of insulinomas to regions of the pancreas by intraarterial calcium stimulation: the NIH experience. J Clin Endocrinol Metab 2009; 94: 1074-1080 http://dx.doi.org/10.1210/jc.2008-1986

[65] KALTSAS GA, BESSER GM, GROSSMAN AB. The diagnosis and medical management of advanced neuroendocrine tumors. Endocr Rev 2004; 25: 458-511 http://dx.doi. org/10.1210/er.2003-0014

[66] HIRAMOTO JS, FELDSTEIN VA, LABERGE JM, NORTON JA. Intraoperative ultrasound and preoperative localization detects all occult insulinomas. Arch Surg 2001; 136: 1020-1026 http://dx.doi.org/10.1001/archsurg.136.9.1020

[67] GROVER AC, SKARULIS M, ALEXANDER HR, PINGPANK JF, JAVOR ED et al. A prospective evaluation of laparoscopic exploration with intraoperative ultrasound as a technique for localizing sporadic insulinomas. Surgery 2005; 138: 1003-1008 http://dx.doi.org/10.1016/j.surg.2005.09.017

[68] BERENDS FJ, CUESTA MA, KAZEMIER G, VAN EIJCK $\mathrm{CH}, \mathrm{DE}$ HERDER WW et al. Laparoscopic detection and resection of insulinomas. Surgery 2000; 128: 386-391 http:// dx.doi.org/10.1067/msy.2000.107413

[69] KAUHANEN S, SEPPANEN M, MINN H, NUUTILA P. Clinical PET Imaging of Insulinoma and Beta-Cell Hyperplasia. Curr Pharm Des 2010; 16: 1550-1560 http://dx.doi. org/10.2174/138161210791164090

[70] KRENNING EP, KOOIJ PP, BAKKER WH, BREENAN WA, POSTEMA PT et al. Radiotherapy with a radiolabelled somatostatin analogue, [111In-DTPA-D-Phe1]-octreotide. A case history. Ann N Y Acad Sci 1994; 733: 496-506. http://dx.doi. org/10.1111/j.1749-6632.1994.tb17300.x

[71] WILD D, CHRIST E, CAPLIN ME, KURZAWINSKI TR, FORRER F et al. Glucagon-like peptide-1 versus somatostatin receptor targeting reveals 2 distinct forms of malignant insulinomas. J Nucl Med 2011; 52: 1073-1078 http://dx.doi. org/10.2967/jnumed.110.085142

[72] CHRIST E, WILD D, FORRER F, BRANDLE M, SAHLI R et al. Glucagon-like peptide-1 receptor imaging for localization of insulinomas. J Clin Endocrinol Metab 2009; 94: 4398-4405 http://dx.doi.org/10.1210/jc.2009-1082

[73] WILD D, WICKI A, MANSI R, BEHE M, KEIL B et al. Exendin-4-based radiopharmaceuticals for glucagon like peptide-1 receptor PET/CT and SPECT/CT.J Nucl Med 2010; 51: 1059-1067 http://dx.doi.org/10.2967/jnumed.110.074914

[74] REUBI JC, WASSER B. Concomitant expression of several peptide receptors in neuroendocrine tumours: molecular basis for in vivo multireceptor tumour targeting. Eur J Nucl Med Mol Imaging 2003; 30: 781-793 http://dx.doi.org/10.1007/ s00259-003-1184-3

[75] SOWA-STASZCZAK A, PACH D, MIKOLAJCZAK R, MACKE H, JABROCKA-HYBEL A et al. Glucagon-like peptide-1 receptor imaging with [Lys40(Ahx-HYNIC- 99mTc/ EDDA)NH2]-exendin-4 for the detection of insulinoma Eur J Nucl Med Mol Imaging 2013; 40: 524-31 http://dx.doi. org/10.1007/s00259-012-2299-1 
[76] ERIKSSON B, ORLEFORS H, OBERG K, SUNDIN A, BERGSTROM $M$ et al. Developments in PET for the detection of endocrine tumours. Best Pract Res Clin Endocrinol Metab 2005; 19: 311-324 http://dx.doi.org/10.1016/j. beem.2004.11.001

[77] KAUHANEN S, SEPPANEN M, MINN H, GULLICHSEN R, SALONEN A et al. Fluorine-18-L-dihydroxyphenylalanine (18F-DOPA) positron emission tomography as a tool to localize an insulinoma or beta-cell hyperplasia in adults patients. J Clin Endocrinol Metab 2007; 92: 1237-1344 http://dx.doi. org/10.1210/jc.2006-1479

[78] MONTRAVERS F, KERROU K, NATAF V, HUCHET V, LOTZ JP et al.Impact of fluorodihydroxyphenylalanine- $18 \mathrm{~F}$ positron emission tomography on management of adult patients with documented or occult digestive endocrine tumors. J Clin Endocrinol Metab 2009; 94: 1295-1301 http://dx.doi. org/10.1210/jc.2008-1349

[79] TESSONNIER L, SEBAG F, GHANDER C, DE MICCO C, REYNAUD R et al. Limited value of 18F-F-DOPA PET to localize pancreatic insulin-secreting tumors in adults with hyperinsulinemic hypoglycemia. J Clin Endocrinol Metab 2010; 95: 303-307 http://dx.doi.org/10.1210/jc.2009$\underline{1357}$

[80] ORLEFORS H, SUNDIN A, GARSKE U, JUHLIN C, OBERG K et al. Whole-body (11)C-5-hydroxytryptophan positron emission tomography as a universal imaging technique for neuroendocrine tumors: comparison with somatostatin receptor scintigraphy and computed tomography. J Clin Endocrinol Metab 2005; 90: 3392-3400 http://dx.doi.org/10.1210/jc.2004-1938

[81] KOOPMANS KP, NEELS OC, KEMA IP, ELSINGA PH, SLUITER WJ et al. Improved staging of patients with carcinoid and islet cell tumors with $18 \mathrm{~F}$-dihydroxy-phenyl-alanine and 11C-5-hydroxy-tryptophan positron emission tomography. J Clin Oncol 2008; 26: 1489-95 http://dx.doi.org/10.1200/ JCO.2007.15.1126

[82] GABRIEL M, DECRISTOFORO C, KENDLER D, DOBROZEMSKY G, HEUTE D et al. 68Ga-DOTA-Tyr3-octreotide PET in neuroendocrine tumors: comparison with somatostatin receptor scintigraphy and CT. J Nucl Med 2007; 48: 508-518 http://dx.doi.org/10.2967/jnumed.106.035667

[83] AMBROSINI V, CAMPANA D, NANNI C, MARZOLA MC, RUBELLO D, FANTI S. 68Ga DOTANOC PET/CT Detects Primary Malignant Insulinoma. Ciln Nucl Med. 2015; 40: 132-133 http://dx.doi.org/10.1097/RLU.0000000000000447

[84] SADOWSKI SM, NEYCHEY V, COTTLE-DELISLE C, MERKEL R, YANG LA. Detection of insulinoma using 68Gallium-DOTATATE PET/CT: a case report. Gland Surg2014; 3: E1-E5

[85] FINLAYSON E, CLARK OH. Surgical treatment of insulinomas. Surg Clin N Am 2004; 84: 775-785 http://dx.doi. org/10.1016/j.suc.2004.02.004

[86] FENDRICH V, WALDMAN J, BARTSCH DK, LANGER DK. Surgical management of pancreatic endocrine tumors. Nat Rev Clin Oncol 2009; 6: 419-428 http://dx.doi.org/10.1038/ nrclinonc.2009.82

[87] REHMAN A. Insulinoma - a deceptive endocrine tumour. J Pak Med Assoc 2011; 61: 911-914
[88] AKERSTROM G, HELLMAN P. Surgery on neuroendocrine tumours. Best Pract Res Clin Endocrinol Metab 2007; 21: 87-109 http://dx.doi.org/10.1016/j.beem.2006.12.004

[89] ZHAO YP, ZHAN HX, ZHANG TP, CONG L, DAI MH et al. Surgical management of patients with insulinomas: Result of 292 cases in a single institution. J Surg Oncol 2011; 103: 169-174 http://dx.doi.org/10.1002/jso.21773

[90] HIRONO S, TANI M, KAWAI M, INA S, NISHIOKA R. et al. A central pancreatectomy for benign or low-grade malignant neoplasms. J Gastrointest Surg 2009; 13: 1659-1665 http:// dx.doi.org/10.1007/s11605-009-0934-3

[91] CRIPPA S, BASSI C, SALVIA R, FALCONI M, BUTTURINI $\mathrm{G}$ et al. Enucleation of pancreatic neoplasms. Br J Surg 2007; 94: 1254-1259 http://dx.doi.org/10.1002/bjs.5833

[92] BOUKHAM MB, KARAM JM, SHAVER J, SIPERSTEIN AE, DELORIMIER AA et al. Localization of insulinomas. Arch Surg 1999; 134: 822-823

[93] HIRAMOTO JS, FELDSTEIN VA, LABERGE JM, NORTON JA. Intraoperative ultrasound and preoperative localization detects all occult insulinomas. Arch Surg 2001; 136: 1020-1025 http://dx.doi.org/10.1001/archsurg.136.9.1020

[94] CARNEIRO DM, LEVI JU, IRVIN GL, Rapid insulin assay for intraoperative confirmation of complete resection of insulinomas. Surgery 2002; 132: 937-942 http://dx.doi.org/10.1067/ msy.2002.128481

[95] MABRUT JY, FERNANDEZ-CRUZ L. AZAGRA JS, BASSI C, DELVAUX G et al. Laparoscopic pancreatic resection: results of a multicentre European study of 127 patients. Surgery 2005; 137: 597-605 http://dx.doi.org/10.1016/j.surg.2005.02.002

[96] LO CY, LO CM, FAN ST. Role of laparoscopic ultrasonography in intraoperative localization of pancreatic insulinoma. Surg Endosc 2000; 14: 1131-1135 http://dx.doi.org/10.1007/ $\underline{\mathrm{s} 004640010032}$

[97] FERNANDO-CRUZ L, BLANCO L, COSA R, RENODN H. Is laparoscopic resection adequate in patients with neuroendocrine pancreatic tumors? World J Surg 2008; 32: 904-917 http://dx.doi.org/10.1007/s00268-008-9467-2

[98] JENSEN RT, BERNA MJ, BINGHAM MD, NORTON JA. Inherited pancreatic endocrine tumor syndromes: advances in molecular pathogenesis, diagnosis, management and controversies. Cancer 2008; 113: 1807-1843 http://dx.doi. org/10.1002/cncr.23648

[99] NORTON JA, FANG TD, JENSEN RT. Surgery for gastrinoma and insulinoma in multiple endocrine neoplasia type I. J Natl Compr Cancer 2006; 4: 148-153

[100] DEMEURE MJ, KLONOFF DC, KARAM JH, et al. Insulinomas associated with multiple endocrine neoplasia type I: the need for a different surgical approach. Surgery 1991; 110: 998-1004

[101] SERVICE FJ, DALE AJ, ELVEBACK LR, JIANG NS. Insulinoma: clinical and diagnostic features of 60 consecutive cases. Mayo Clin Proc. 1976; 51: 417-429

[102] SARMIENTO JM, QUE FG, GRANT CS, THOMPSON GB, FARREL MB et al. Concurrent resections of pancreatic islet cell cancers with synchronous hepatic metastases: outcomes of an aggressive approach. Surgery 2002; 132: 976-982 http:// dx.doi.org/10.1067/msy.2002.128615 
[103] THOMPSON GB, VAN HEERDEN JA, GRANT CS, CARNEY JA, ILSTRUP DM. Islet cell carcinomas of the pancreas: a twenty-year experience. Surgery 1988; 104: 1011-1017

[104] SARMIENTO JM, QUE FG, Hepatic surgery for metastases from neuroendocrine tumors. Surg Oncol Clin N Am 2003; 12: 231-242 http://dx.doi.org/10.1016/S1055-3207(02)00076-5

[105] STEINMULLER T, KIANMANESH R, FALCONI M, SCARPA A, TAAL B et al. Consensus guidelines for the management of patients with liver metastases from digestive (neuro)endocrine tumors: foregut, midgut, hindgut, and unknown primary. Neuroendocrinology 2008; 87: 47-62 http://dx.doi.org/10.1159/000111037

[106] CHANDRA P, YARANDI SS, KHAZAI N, JACOBS S, UMPIERREZ GE. Management of intractable hypoglycemia with Yttrium-90 radioembolization in a patient with malignant insulinoma. Am J Med Sci 2010; 340: 414-417 http://dx.doi. org/10.1097/MAJ.0b013e3181ee7be2

[107] DE HERDER WW, SCHAIK E, KWEKKEBOOM D, FEELDERS RA. New therapeutic options for metastatic malignant insulinomas. Clin Endocrinol 2011; 75: 277-284 http://dx.doi.org/10.1111/j.1365-2265.2011.04145.x

[108] KRESS O, WAGNER HJ, WIED M, KLOSE KJ, ARNOLD R. et al. Transarterial chemoembolization of advanced liver metastases of neuroendocrine tumours - a retrospective single-centre analysis. Digestion 2003; 68: 94-101 http://dx.doi. org/10.1159/000074522

[109] LE TREUT YP, GREGOIRE E, BELGHITI J, BOILLOT O, SOUBRANE $O$ et al. Predictors of long term survival after liver transplantation for metastatic endocrine tumors: an 85 -case French multicentric report. Am J Transplant 2008; 8: 12051213 http://dx.doi.org/10.1111/j.1600-6143.2008.02233.x

[110] ERIKSSON B, ANNIBALE B, BAJETTA E., MITRY E, PAVEL M. et al. ENETS Consensus Guidelines for the Standards of Care in Neuroendocrine Tumors: chemotherapy in patients with neuroendocrine tumors. Neuroendocrinology 2009; 90 : 214-219 http://dx.doi.org/10.1159/000225950

[111] KALTAS GA, BESSER M, GROSSMAN AB. The diagnosis and medical management of advanced neuroendocrine tumors. Endocr Rev 2004; 26: 468-511

[112] STROSBERG JR, FINE RL, CHOI J, NASIR A, COPPOLA $D$ et al. First-line chemotherapy with capecitabine and tenozolomid in patients with metastatic pancreatic endocrine carcinomas. Cancer 2011; 117: 268-275 http://dx.doi. org/10.1002/cncr.25425

[113] RAMANATHAN RK, CNAAN A, HAHN RG, CARBONE PP, HALLER DG. Phase II trial of dacarbazine (DTIC) in advanced pancreatic islet cell carcinoma. Study of the Eastern Cooperative Oncology Group E6282. Ann Oncol 2001; 12: 1139-1143 http://dx.doi.org/10.1023/A:1011632713360

[114] HAINSWORTH JD, SPIGEL DR, LITCHY S. Phase II trial of paclitaxel, carboplatin, and etoposid in advanced poorly differentiated neuroendocrine carcinoma: a Minnie Pearl Cancer Research Network Study. J Clin Oncol 2006; 24: 3548-3554 http://dx.doi.org/10.1200/JCO.2005.05.0575

[115] YAO JC, SHAH MH, ITO T, BOHAS CL, WOLIN EM et al. Everolimus for advanced pancreatic neuroendocrine tumors.
N Engl J Med 2011; 364: 514-523 http://dx.doi.org/10.1056/ NEJMoa1009290

[116] KULKE MH, BERGSLAND EK, YAO JC. Glycemic control in patients with insulinoma treated with everolimus. N Engl J Med 2009; 360: 195-197 http://dx.doi.org/10.1056/NEJMc0806740

[117] FEIBRICH HB, SIEMERINK EJ, BROUWERS AH, LINKS TP, REMKES WS et al. Everolimus induces rapid plasma glucose normalization in insulinoma patients by effects on tumor as well as normal tissues. Oncologist 2011; 16: 783-787 http:// dx.doi.org/10.1634/theoncologist.2010-0222

[118] ONG GSY, HENLEY DE, HURLEY D, TURNER JH, CLARINGBOLD PG et al. Therapies for the medical management of persistent hypoglycemia in two cases of inoperable malignant insulinoma. Eur J Endocrinol 2010; 162: 1001-1008 http:// dx.doi.org/10.1530/EJE-09-1010

[119] RAYMOND E, DAHAN L, RAOUL JL, BANG YJ, BORBATH I et al. Sunitinib malate for the treatment of pancreatic neuroendocrine tumors. N Engl J Med 2011; 364: 501-513 http:// dx.doi.org/10.1056/NEJMoa1003825

[120] KWEKKEBOOM DJ, KRENNING EP, LEBTAHI R, KOMMINOTH P, KOS-KUDLA B et al. ENETS Consensus Guidelines for the Standards of Care in Neuroendocrine Tumors: peptide receptor radionuclide therapy with radiolabelled somatostatin analogs. Neuroendocrinology 2009; 90: 220-226 http://dx.doi.org/10.1159/000225951

[121] KWEKKEBOOM DJ, TEUNISSEN JJ, BAKKER WH, KOOIJ PP, DE HERDER WW et al. Radiolabelled somatostatin analog [177Lu-DOTA0, Tyr3] octreotate in patients with endocrine gastroenteropancreatic tumors. J Clin Oncol 2005; 23: 2754-2762 http://dx.doi.org/10.1200/JCO.2005.08.066

[122] KWEKKEBOOM DJ, DE HERDER WW, KAM BL, VAN EIJICK CH, VAN ESSEN $M$ et al. Treatment with the radiolabelled somatostatin analog [177Lu-DOTA0, Tyr3] octreotate: toxicity, efficacy, and survival. J Clin Oncol 2008; 26: 2124-2130 http://dx.doi.org/10.1200/JCO.2007.15.2553

[123] ALTSZULER N, MORARU E, HAMPSHIRE J. On the mechanism of diazoxide-induced hyperglycemia. Diabetes 1977; 26: 931-935 http://dx.doi.org/10.2337/diab.26.10.931

[124] Stefanini P, Carboni M, Patrassi N, De Bernardinis G, Negro P. Problems of the management of insulinomas. Review of 132 cases treated with medical measures. Acta Diabetol Lat 1974; 11,71-77 http://dx.doi.org/10.1007/BF02581941

[125] VEZZOSI E, BENNET A, COURBON F, CARON P. Shortand long-term somatostatin analogue treatment in patients with hypoglycaemia related to endogenous hyperinsulinism. Clin Endocrinol 2008; 68: 904-911. http://dx.doi.org/10.1111/ j.1365-2265.2007.03136.x

[126] OBERG K, KVOLS L, CAPLIN M, DELlE FAVE G, DE HERDER WW et al. Consensus report on the use of somatostatin analogs for the management of neuroendocrine tumors of the gastroenteropancreatic system. Ann Oncol 2004; 15: 966-973 http://dx.doi.org/10.1093/annonc/mdh216

[127] RINKE A, MULLER HH, SHADE-BRITTINGER C, KLOSE KJ, BARTH P, Wied M et al. Placebo-controlled double blind, prospective, randomized study on the effect of octreotide LAR in the control of tumor growth in patients with metastatic neuroendocrine midgut tumors: a report from the PROMID 
Study Group. J Clin Oncol 2009; 27: 4656-4663 http://dx.doi. org/10.1200/JCO.2009.22.8510

[128] CAPLIN ME, PAVEL M, CWIKLA JB, PHAN AT, RADERE $\mathrm{M}$ et al. Lanreotide in metastatic enteropancreatic neuroendocrine tumors. N Engl J Med 2014; 371: 224-233 http://dx.doi. org/10.1056/NEJMoa1316158

[129] PREUMONT V, MERMEJO LM, DAMOISSEAUX P, LACROIX A, MAITER D. Transient efficacy of octreotid and pasireotid (SOM230) treatment in GIP-dependent Cushing's syndrome. Horm Metab Res 2011; 43: 287-293 http://dx.doi. org/10.1055/s-0030-1270523

[130] NOVOTNY J, JANKU F, MARES P, PETRUZELKA L. Symptomatic control of hypoglycaemia with prednisone in refractory metastatic pancreatic insulinoma. Support Care Cancer 2005; 13: 760-762 http://dx.doi.org/10.1007/s00520005-0840-5

[131] FAISS S, PAPE UF, BOHMIG M, DORFFEL Y, MANSMANN $\mathrm{U}$ et al. Prospective, randomized, multicentre trial on the antiproliferative effect of lanreotide, interferon alfa, and their combination for therapy of metastatic neuroendocrine gastroenteropancreatic tumors--the International Lanreotide and Interferon Alfa Study Group. J Clin Oncol 2003; 21:2689-2696 http://dx.doi.org/10.1200/JCO.2003.12.142

[132] ERIKSSON B, OBERG K. An Update of the medical treatment of malignant endocrine pancreatic tumors. Acta Oncol 1993; 32: 203-208 http://dx.doi.org/10.3109/02841869309083913 